\title{
Clinical effect of porous titanium mesh with cross-linked collagen membrane for guided bone regeneration
}

\author{
Su-Hyeon Jung ${ }^{1}$, Hee-Yung Chang ${ }^{1,2}$, Hyung-Keun You ${ }^{1,2}$, Sung-Hee $\mathrm{Pi}^{1,2 \star}$ \\ ${ }^{1}$ Department of Periodontology, Wonkwang University College of Dentistry, Iksan, Korea \\ ${ }^{2}$ Institute of Wonkwang Dental Research, Wonkwang University College of Dentistry, Iksan, Korea
}

\begin{abstract}
Titanium mesh, a barrier membrane, has excellent mechanical properties and space maintaining ability. However, one of its disadvantages is that soft tissue over the membrane could be interposed through the pore of the mesh. Conversely, the cross-linked collagen membrane has good soft tissue reaction and reduces the migration of epithelial cells to the guided bone regeneration site. Therefore, we performed guided bone regeneration using a combination of collagen membrane and titanium mesh and analyzed the clinical results. The patients were divided into two groups. Only titanium mesh was used for guided bone regeneration in group A, and a combination of titanium mesh and collagen membrane was used in group B. The degree of soft tissue interposition over the titanium mesh was evaluated after titanium mesh removal, and the surface bone quality was observed. The obtained bone height was measured in the panoramas based on the adjacent tooth cemento-enamel junction, and the bone density was measured using the Hounsfield scale on cone beam computed tomography before titanium mesh removal. In group A, the average soft tissue interposition was $31.50 \%$, and the bone quality was poor when the interposed soft tissue was removed. Therefore, additional bone grafting was performed during implant placement in one case. In group B, there was almost no soft tissue interposition between the titanium mesh pores, and no additional bone graft was performed during implant placement. The combination of two membranes provides a favorable vertically obtained bone height and excellent surface bone quality without soft tissue interposition.
\end{abstract}

Key Words: Bone regeneration, Dental implantation, Membranes, Radiography

(c) This is an open-access article distributed under the terms of the Creative Commons Attribution Non-Commercial License (http://creativecommons.org/licenses/by-nc/4.0) which permits unrestricted noncommercial use, distribution, and reproduction in any medium, provided the original work is properly cited.

\section{서 론}

발치 후 위축된 치조골을 가진 환자에서 임플란트 식립을 위 해 치조골을 재건하는 다양한 술식들이 개발되었다. 이 중 골유 도재생술은 높은 예지성을 보이는 술식으로 장기적인 안정성을 보이기 때문에 오늘날 임상에서 널리 사용되고 있다[1,2].

수평적, 수직적으로 심하게 위축된 치조골에서 골유도재생 술을 시행할 때, 많은 임상가들은 어떤 차단막을 이용할 것인 가에 대하여 고민한다. 흡수성 차단막은 제거를 위한 2 차 수술
은 필요하지 않지만, 공간 유지 효과가 떨어져 골 형성량을 예측 할 수 없다는 단점이 있고[3], 비흡수성 막 중 하나인 expanded polytetrafluoroethylene (E-PTFE)는 결손부를 지지할 골벽이 부족할 경우 screw나 pin으로 공간 유지는 가능하나, screw나 pin 사용하는 데 있어 판막 거상량 증가, 술 후 부종, 높은 비용, 술식의 어려움 등의 단점이 존재한다[4,5]. E-PTFE의 이런 단점 에 대한 대안으로 티타늄 막(titanium mesh)을 사용할 수 있는 데, 티타늄 막은 기계적 물성이 아주 우수하여 screw나 pin 없 이도 공간 유지 능력이 뛰어나 광범위한 공간에 이식된 골 이식

Received August 7, 2019; Revised September 6, 2019; Accepted September 6, 2019

Corresponding author: Sung-Hee Pi, Department of Periodontology, Wonkwang University College of Dentistry, 895 Muwang-ro, Iksan 54538, Korea. Tel: +82-63-859-2966, Fax: +82-63-857-4002, E-mail: pshperio@wku.ac.kr 
재도 안정적으로 유지할 수 있다는 장점이 있다[6.7]. 또한 조작 성이 좋아 어떠한 형태의 골 결손부에도 적합이 용이하다[8].

하지만 많은 임상적 경우에서 티타늄 막은 재수술 시 보면, 연 조직이 개재되어 그로 인해 불량한 표면 골질을 보일 때가 있다. 그렇다면 티타늄 막의 공간 유지능은 그대로 활용하면서 연조 직 개재를 막음으로써 더 좋은 골질을 얻을 방법은 없을까? 우 리는 세포 차단성이 있는 교차결합된 콜라겐 막을 티타늄 막과 함께 사용하면 이를 해결할 수 있을 것이라고 생각하였다. 이 연 구의 목적은 골유도재생술 시 티타늄 막과 교차결합된 콜라겐 막을 함께 사용했을 때의 임상적 효과를 평가하는 것이다.

\section{대상 및 방법}

\section{실험 대상}

이 연구는 원광대학교 치과병원 치주과에 내원한 환자 중 위 축된 치조골로 인해 수평적, 수직적 골증대가 필요하여 골유도 재생술을 시행한 환자를 대상으로 하였다. 대상 환자들은 심 한 골소실로 인하여 단계적으로 골 이식을 먼저 시행한 후 임플 란트를 식립하는 것이 추천되는 경우였다. 연구에 포함된 환자 는 총 6명(남성 4명, 여성 2명)으로 나이는 46세에서 66세(평균 57.8 세)였다. 6 명의 환자 중 3 명의 환자는 티타늄 막을 단독으 로 사용하였고(A군), 다른 3명의 환자에서는 티타늄 막과 교차 결합된 콜라겐 막을 함께 사용하였다(B군). 6명의 환자 모두 골 유도재생술 술식에 영향을 줄만한 전신병력 및 흡연력은 없었 으며, 시행한 부위 및 환자 정보는 Table 1과 같다. 본 연구는 원 광대학교 치과대학병원 기관생명윤리위원회의 승인을 받았다 (IRB no. WKDIRB201906-03).

Table 1. Information of subjects of study

\begin{tabular}{lccccc}
\hline & Patient & Age (y) & Sex & $\begin{array}{c}\text { Systemic } \\
\text { diseases }\end{array}$ & Site \\
\hline Group A & 1 & 58 & M & NS & $\# 26,27$ \\
& 2 & 46 & M & NS & $\# 14-17$ \\
& 3 & 62 & F & NS & $\# 26,27$ \\
Group B & 4 & 53 & F & NS & $\# 25-27$ \\
& 5 & 66 & M & NS & $\# 36$ \\
& 6 & 62 & M & NS & $\# 31-42$ \\
\hline
\end{tabular}

Group A, only titanium mesh was used for guided bone regeneration; Group B, combination of titanium mesh and collagen membrane was used. M, male; F, female; NS, not significant.

\section{술식 과정}

수술 전 통법의 소독 방법으로 수술 부위를 소독하였으며, 수술 부위의 국소마취는 $2 \%$ 염산리도카인 에피네프린 주사 (1:100,000; Yuhan Corp., Seoul, Korea)로 침윤마취를 시행 하였다. 술부 치조정 절개 후 전층 판막을 거상한 후 골 표면 위 의 잔존 육아조직을 제거하였다. 본 연구에서 사용한 티타늄 막 은 Cytoflex ${ }^{\circledR}$ mesh (0.5 mm Thickness; Unicare Biomedical, Inc., Laguna Hills, CA, USA), 교차결합된 콜라겐 막은 Ossix ${ }^{\circledR}$ plus (OraPharma Inc., Warminster, PA, USA)였다. 골 결손부 위를 치주탐침을 이용하여 크기를 재고, 사용할 차단막을 작도 하였다. 티타늄 막은 막의 측방으로 결합조직 개재가 없도록 막 을 조작하여, 골 결손부위에 맞춰 적합시켰다. 티타늄 막 사용 으로 인한 연조직 열개가 발생하지 않도록 협측 판막에 이완 절 개를 시행하여 일차 봉합을 이룰 수 있게 판막을 조작하였다. 골 이식재로는 탈회동결건조골(irradiated allogenic cancellous bone \& marrow; Rocky Mountain Tissue Bank, Aurora, CO, USA)과 함께 탈단백우골(Bio-Oss; Geistlich, Chester, UK)을 혼합하여 사용하였다. 술부에 골 이식재를 넣고 차단막을 적합 시켜 위치시키는데, 티타늄 막과 교차결합된 콜라겐 막 조합군 은 골 이식재 상방에 티타늄 막을 먼저 위치시키고 그 위로 콜라 겐 막을 올렸다. 이 때 콜라겐 막과 티타늄 막은 채워진 골 이식 재를 완전히 덮도록 하였다. 그 후 비흡수성 봉합사(4-0 Ethi$\mathrm{lon}^{\circledR}$; Ethicon Inc., Cincinnati, OH, USA)를 이용하여 봉합하 였다. 4-6개월 후 re-entry하여 임플란트를 식립하였다. 골유도 재생술 전과 술 후 4-6개월 지나 re-entry 직전에 cone beam computed tomography (CBCT)를 촬영하였다.

\section{측정방법}

\section{연조직 개재 정도}

Re-entry 시 판막 거상 후 티타늄 막을 제거하고, 제거한 티타 늄 막 상에서 연조직 개재 정도를 평가하였다. 제거한 티타늄 막 면적 대비 연조직이 개재된 면적을 퍼센트(\%)로 계산하였다.

$$
\frac{\text { 티타늄 막 상부 연조직 면적 }}{\text { 제거한 티타늄 막의 면적 }} \times 100
$$

\section{표면 골질}

Re-entry 시 티타늄 막 제거 직후의 표면 골질에 대하여 육안 으로 평가하였다. $\mathrm{A}$ 군과 $\mathrm{B}$ 군을 골 이식재 잔존 여부와 골 표면 의 연조직 개재 정도, 골형성이 되지 않은 사강 여부 등에 대하 여 비교하였다. 


\section{방사선적 분석}

파노라마: 파노라마 사진은 골유도재생술 전과, 수술 직후, re-entry 직전 촬영하였다. 촬영한 파노라마에서 인접치아 cemento-enamel junction (CEJ)을 기준으로 하여 수직적 골 높이를 방사선적으로 측정하였다. 측정은 방사선사진 프로그램 (INFINITT PACS; INFINITT Healthcare Co., Seoul, Korea)상 계측 도구를 이용하였다. 측정값을 이용하여 defect의 수직적 높이와 guided bone regeneration (GBR) 후 생성된 골의 높이 (obtained bone height)를 측정하였다(Fig. 1).

Cone beam computed tomography: 골질을 평가함에 있 어서 본 연구에서 조직학적 분석은 시행하지 않았다. 임플란 트 drilling 시 술자의 감각은 주관적인 것이기 때문에 이를 보 다 객관적으로 평가하기 위해 Ondemand $3 \mathrm{D}^{\mathrm{TM}}$ soft (version 1.0.10.6388; Cybermed, Seoul, Korea)를 이용하여 Hounsfield unit (HU)을 측정하여 골성숙도를 비교하였다. Yamada 등[9]에 의하면 골유도재생술 부위의 골이 성숙할수록 골유도재 생술 부위의 $\mathrm{HU}$ 값은 시간이 지날수록 증가하여 native bone과 유사해진다고 하였다. 따라서 본 연구에서는 Ondemand 프로 그램을 이용하여 새로 얻어진 3D 모델에서 region-of-interest (ROI) 기능을 이용하여 골유도재생술 부위와 native bone의 $\mathrm{HU}$ 값을 비교하였다. 골유도재생술 부위에서의 ROI는 인접치 아의 $\mathrm{CEJ}$ 를 기준으로 $5 \mathrm{~mm}$ 떨어진 부위를 근심 경계로 하고 티 타늄 막과 가장 인접한 부위를 하부 경계로 하는 $10 \mathrm{~mm} \times 10$ $\mathrm{mm}$ 크기를 설정하여 측정하였다. native bone에서의 ROI는

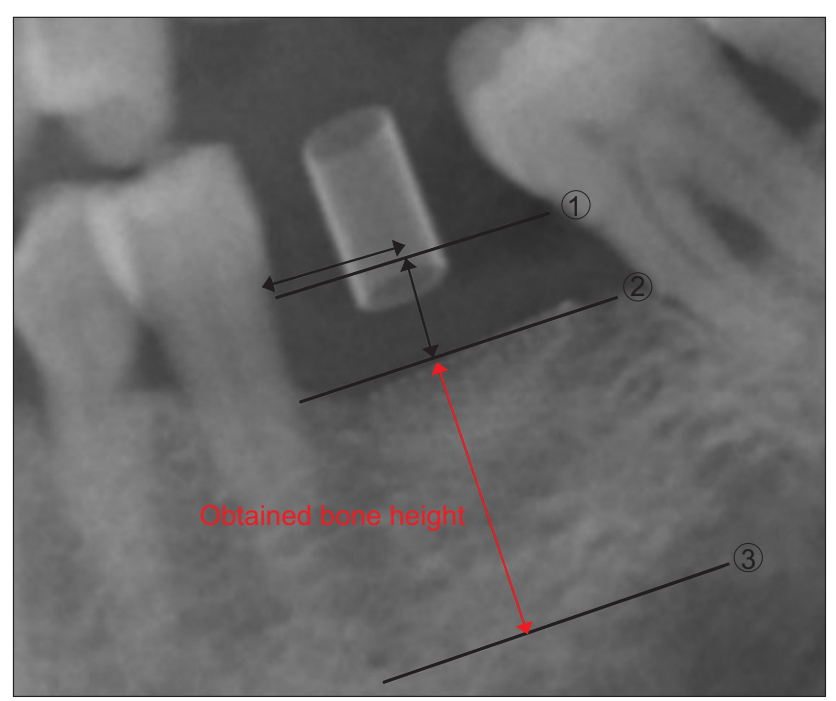

Fig. 1. Measurement vertically obtained bone height in panorama. (1) Line connected cemento-enamel junction of both adjacent teeth. (2) Line paralled with (1), at the most coronal point of obtained bone after guided bone regeneration. (3) Line paralled with (1), the most apical point of bone defect.
같은 악골의 반대편 무치악 부위에서 $10 \mathrm{~mm} \times 10 \mathrm{~mm}$ 크기를 설정하여 측정하였다. $\mathrm{A}, \mathrm{B}$ 군 간에 골유도재생술 부위와 native bone의 HU 값의 근사한 정도의 차이를 통계적(Mann-Whitney test)으로 분석하였다.

\section{결 과}

모든 환자에서 치유과정 중 차단막의 노출이나 감염 등의 합 병증은 없었고 임상적, 방사선적으로 모두 양호한 결과를 보였 다. 임플란트의 초기 고정은 모두 우수하였다.

파노라마 방사선사진상 수직적인 골 증대량을 측정해 보았을 때 두 군 모두 $5 \mathrm{~mm}$ 이상의 수직적 골 증대를 얻었다(Table 2).

\section{연조직 개재 정도}

$\mathrm{A}$ 군은 평균적으로 $31.50 \%$ 의 연조직 개재가 있었다. $\mathrm{B}$ 군에서 는 이와 대조적으로 매우 적은 양의 연조직 개재량을 보이거나 연조직 개재가 없었다(Table 3, Fig. 2).

Table 2. Obtained vertical bone height in panorama

\begin{tabular}{cccc} 
& Patient & $\begin{array}{c}\text { Size of } \\
\text { defects }(\mathbf{m m})\end{array}$ & OBH (mm) \\
\hline Group A & 1 & 6.81 & 5.30 \\
& 2 & 8.38 & 7.27 \\
Group B & 3 & 7.55 & 6.40 \\
& 4 & 6.30 & 6.16 \\
& 5 & 8.81 & 7.08 \\
& 6 & 10.28 & 9.97 \\
\hline
\end{tabular}

Group A, only titanium mesh was used for guided bone regeneration; Group B, combination of titanium mesh and collagen membrane was used. $\mathrm{OBH}$, obtained bone height.

Table 3. Soft tissue intervention

\begin{tabular}{cccc}
\hline & Patient & $\begin{array}{c}\text { Soft tissue inter- } \\
\text { vention (\%) }\end{array}$ & Average (\%) \\
\hline Group A & 1 & 22.08 & 31.50 \\
& 2 & 49.12 & \\
Group B & 3 & 23.31 & 1.67 \\
& 4 & 2.98 & \\
& 5 & 2.02 & \\
\hline
\end{tabular}

Group A, only titanium mesh was used for guided bone regeneration; Group B, combination of titanium mesh and collagen membrane was used. 


\section{표면 골질}

$\mathrm{A}$ 군은 $\mathrm{B}$ 군보다 육안상 관찰되는 표면 골질이 좋지 않았다 (Fig. 3). A군의 환자 1 은 티타늄 막을 제거하는 중에 골조직이 손상 받아 골 파편이 떨어져 나왔고 해당 부위에 사강이 발생하 였다. $\mathrm{A}$ 군의 환자 2 는 구개측으로 충분한 골이 형성되지 않아 임플란트 식립과 함께 추가적으로 골 이식이 필요하였다. $\mathrm{A}$ 군의 환자 3 은 골 표면에서 연조직 개재와 골 이식재 입자들이 관찰 되었다.

이에 반해 티타늄 막과 콜라겐 막을 조합하여 사용한 B군(Fig. 4)에서는 골 이식재 주변으로 신생골과 함께 연조직 개재가 없 는 좋은 표면 골질이 관찰되었다.

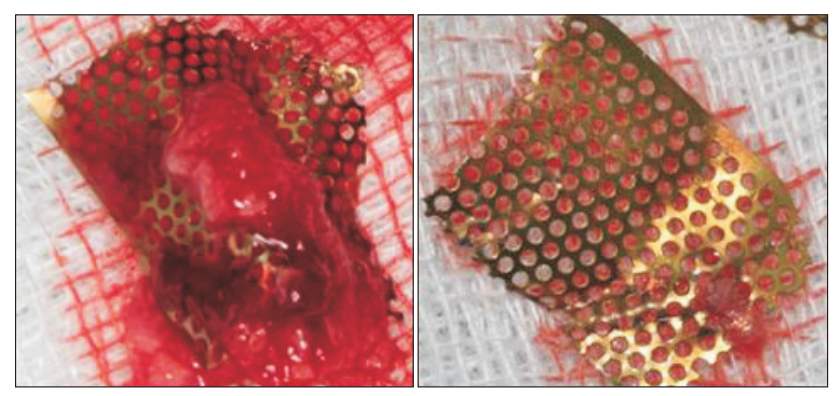

Fig. 2. Left: titanium mesh interposed soft tissue in Group A, Right: titanium mesh in group B. In the group A, average of soft tissue intervention was $31.50 \%$. But in group B, there were very few soft tissue intervention between the titanium mesh.

\section{방사선적 분석}

$\mathrm{CBCT}$ 를 재구성한 $3 \mathrm{D}$ 모델상에서 native bone과 $\mathrm{GBR}$ 부위 의 $\mathrm{HU}$ 를 측정하고 $\mathrm{GBR}$ site $\mathrm{HU} /$ native bone $\mathrm{HU}^{*} 100$ 으로 비 율을 계산하여 골 이식 부위의 $\mathrm{HU}$ 값이 native bone의 $\mathrm{HU}$ 와 얼마나 유사한지 보았다. 이렇게 계산한 $\mathrm{A}$ 군과 $\mathrm{B}$ 군의 측정값 간에 유의한 차이가 있는지 Mann-Whitney test를 시행하였을 때 $p=0.1$ ( $>0.05$ )로 통계적으로 유의한 차이는 보이지 않았다 (Table 4).

\section{고 찰}

성공적인 골유도재생술을 위한 차단막의 조건에는 세포 차 단성, 공간 유지능, 임상적 조작 용이성, 조직 유착, 선택적 세

Table 4. Bone evaluation in CBCT

\begin{tabular}{ccccc}
\hline & Patient & $\begin{array}{c}\text { Native } \\
\text { bone HU }\end{array}$ & $\begin{array}{c}\text { GBR site } \\
\text { HU }\end{array}$ & $\begin{array}{c}\text { GBR HU/ } \\
\text { native bone } \\
\text { HU (\%) }\end{array}$ \\
\hline Group A & 1 & 651.4 & 558.7 & 85.77 \\
& 2 & 441.4 & 310.7 & 70.39 \\
Group B & 3 & 525.1 & 411.6 & 78.39 \\
& 4 & 548.6 & 533.0 & 97.16 \\
& 5 & 726.6 & 693.7 & 95.47 \\
& 6 & 680.6 & 646.2 & 94.95 \\
\hline
\end{tabular}

CBCT, cone beam computed tomography; HU, hounsfield unit; GBR, guided bone regeneration; Group A, only titanium mesh was used for guided bone regeneration; Group B, combination of titanium mesh and collagen membrane was used.

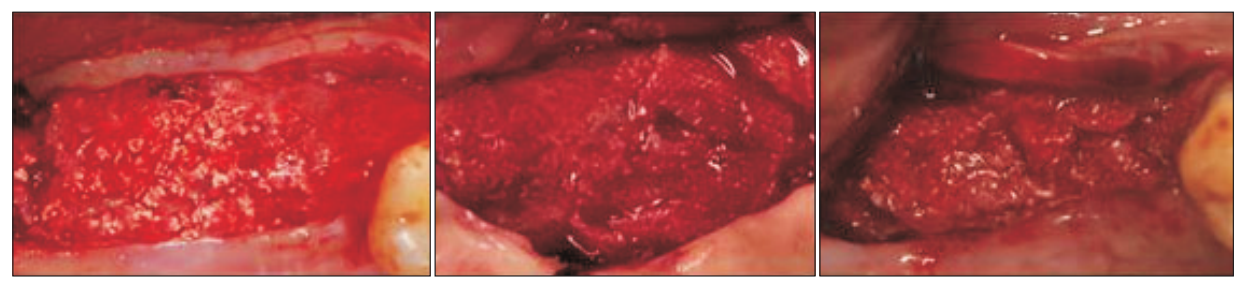

Fig. 3. Group A: in re-entry surgery, after removal of titanium mesh, the bone surface quality of group A is poorer than group B. In details, patient 1 had bone tissue damage during removal of titanium mesh, resulting in a damage on the surface. Patient 2 showed no new bone formation on palatal site. Patient 3 shows a bone graft particle on the surface.
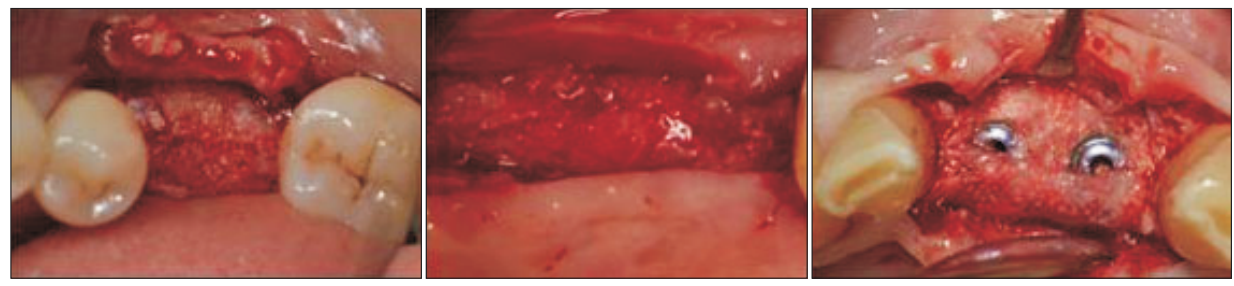

Fig. 4. Group B: in re-entry surgery, after removal of titanium mesh.Group B has very good bone surface quality without soft tissue intervention. 
포 증식, 조직 친화성 등이 있다. 하지만 이러한 조건을 모두 만 족하는 차단막은 존재하지 않으며 임상가가 차단막의 장단점을 고려하여 상황에 적합한 것을 선택하여 사용하는 것이 필요하 다.

1996년 von Arx 등[10]이 티타늄 막을 이용한 구치부 치조골 재생을 보고한 이후, 많은 임상가들이 티타늄 막을 이용하여 골 유도재생술을 시행할 때 임상적으로 유의한 양의 치조골이 형 성되었다고 보고하였다. 티타늄 막은 골 결손부의 형태에 따라 구부려서 적합하는 것이 가능하면서도 충분한 강도가 있어 전 체적인 외형이 무너지지 않을 뿐만 아니라, 뛰어난 공간 유지능 은 이전 연구들을 통하여 그 이점이 충분히 밝혀져 있다 $[8,11-$ 13].

이 티타늄 막에는 pore가 있어 골막으로부터 골 이식재로의 직접적인 혈류 공급을 방해하지 않을 수 있고, 가소성(plasticity)이 생겨 구부려서 골 결손부에 적합시킬 수 있다. 하지만 이 pore 때문에 차단막과 골 사이의 peripheral seal이 깨지고, 이 는 연조직이 pore 사이로 개재되는 것으로 이어진다[14,15]. 티 타늄 막 하방에 생기는 이런 연조직이 초기 노출 시 감염을 막아 주고 더 좋은 혈액 공급을 제공하는 골막과 유사한 조직이라는 연구[16,17]도 있지만, 이는 생성되려면 2-6주가 걸린다고 하고 다른 연구에서는 이런 개재된 연조직이 임상적으로 이점이 없 다고 보고하였다[18].

이번 연구에서는 티타늄 막의 공간 유지능을 통해 원하는 만 큼의 충분한 골은 얻으면서 pore로 인해 개재되는 연조직은 막 아 좋은 표면 골질을 얻기 위해 교차결합된 콜라겐 막의 특징을 이용하였다. 콜라겐 막의 일종인 교차결합된 콜라겐 막은 다른 조직이 골 결손부위로 들어오는 것을 막음으로써 골 재생이 일 어나도록 하는 세포 차단성이 있고, 생체적합성과 감염 저항성 이 우수하고[19], 오래 지속 가능(24주 이상) [20]하다는 장점이 있다.

본 연구의 파노라마 방사선사진상에서 $\mathrm{A}$ 와 $\mathrm{B}$ 군 모두 $5 \mathrm{~mm}$ 이상의 수직적 골 증대를 보였으며, defect의 크기와 얻어진 골 높이를 비교하여 보았을 때 평균적으로 $87 \%$ 의 골 증대가 있었 다(Table 2). Roccuzzo 등[13]은 상, 하악의 수직적 골 증대술을 위해 티타늄 막을 이용한 수술적 protocol을 제시하였는데, 이 연구에 의하면 티타늄 막을 이용하여 수직적으로 $4.8 \mathrm{~mm}$ (4-7 $\mathrm{mm}$, range)의 골 증대를 얻을 수 있었다고 하였고[12], 다른 연 구에서는 2.56-6 mm의 골 증대를 얻는다고 하여[17,21] 본 연 구의 결과와 유사하다.

Re-entry 시 제거한 티타늄 막 상에서의 연조직 개재 정도를 평가하였을 때, $\mathrm{A}$ 군은 평균적으로 $31.50 \%$ 의 연조직 개재가 있 었던 반면에 B군에서는 $1.67 \%$ 의 연조직 개재가 있었다(Table 3). 티타늄 막을 위치시킬 때 측방으로부터의 연조직 개재를 막
기 위해 적합에 유의하였는데 차단막 상방으로의 연조직 개재 는 완벽하게 막을 수는 없었지만 $\mathrm{A}$ 군과 비교했을 때 $\mathrm{B}$ 군에서 유 의할만한 연조직 개재 감소를 보였다. 개재된 연조직은 티타늄 막 제거를 어렵게 하여 제거 중 골 조직이 같이 제거되어 표면골 에 손상을 주었고, 연조직이 개재된 부위에는 새로 형성되는 골 조직이 부족하고 사강이 형성되어 임플란트 식립체 주변으로 골 열개가 발생하여 추가적인 골 이식이 필요하였다.

골유도재생술 부위의 골 성숙도는 CBCT를 분석한 Table 4 를 통해 볼 수 있다. 골 이식 부위의 $\mathrm{HU}$ 값이 native bone HU와 얼 마나 유사한지 보기 위하여 GBR site HU/native bone HU*100 으로 하여 비율로 보았을 때 $\mathrm{A}$ 군은 평균 $78.17 \%, \mathrm{~B}$ 군은 $95.85 \%$ 였다. 두 군 간의 값이 통계적으로 유의하게 차이 나지는 않았지 만, 이는 표본의 수가 적었기 때문으로 추측된다.

티타늄 막과 교차결합된 콜라겐 막을 조합하여 사용하는 것 은 비흡수성 차단막 중 하나인 high-density polytetrafluoroethylene (D-PTFE)과 유사한 효과를 보이는데 D-PTFE는 구 강 내에 노출되어도 감염되지 않고, 공간 유지능도 어느 정도 검 증되어 있는 차단막이다. Cucchi 등[22]의 연구에 따르면, DPTFE만 사용하였을 때와 티타늄 막 상방에 교차결합된 콜라겐 막을 덮어 사용하였을 때의 합병증의 차이를 보았는데, 합병증 발생률이 D-PTFE군에서는 $10 \%$, 티타늄 막과 교차결합된 콜라 겐 막 조합군에서는 $15.8 \%$ 로 통계적으로 유의한 차이가 없었 고, 두 군 모두 유사한 수직적 골 증대량과 골형성을 보였다. 그 러나 D-PTFE는 fixation screw 등이 고정을 위해 필요하고, 티 타늄 막과 같은 탄력성(elasticity)이 없어 창상 열개가 생기며, 가소성이 없어 구부려서 사용할 수가 없다. 그에 반해 티타늄 막 은 tenting screw나 fixation screw 없이 어떠한 형태의 골 결 손부라도 수복이 가능하고, 콜라겐 막만 추가 사용하면 되기 때 문에 훨씬 쉽고, 시간적으로도 단축된다.

이번 연구는 표본 수가 적고, 임플란트 보철을 수복하여 교합 력이 가해진 후 골유도재생술 부위에서의 변화에 대한 $\mathrm{F} / \mathrm{U}$ 가 부 족하다는 한계점이 있지만, 티타늄 막을 단독으로 사용했을 때 보다 티타늄 막과 교차결합된 콜라겐 막을 조합해서 사용함으 로써 더 좋은 표면 골질을 얻고 추가적인 골 이식 없이 예지성 있는 골유도재생술이 가능하다는 것을 확인하였다. 이후 앞서 언급한 한계점을 극복하여 표면 골질이 임플란트 변연골 소실 이나 임플란트 주위염 등과 관련이 있는지 추가적인 연구를 진 행할 수 있을 것이다.

\section{CONFLICTS OF INTEREST}

The authors declare that they have no competing interests. 


\section{ORCID}

\author{
Su-Hyeon Jung \\ https://orcid.org/0000-0002-0752-075X \\ Hee-Yung Chang \\ https://orcid.org/0000-0001-7074-4791 \\ Hyung-Keun You \\ https://orcid.org/0000-0002-4585-0477 \\ Sung-Hee Pi \\ https://orcid.org/0000-0002-1916-6321
}

\section{REFERENCES}

1. Hämmerle $\mathrm{CH}$, Jung RE, Feloutzis A. A systematic review of the survival of implants in bone sites augmented with barrier membranes (guided bone regeneration) in partially edentulous patients. J Clin Periodontol 2002;29 Suppl 3:226-231; discussion 232-233. doi: 10.1034/j.1600051x.29.s3.14.x.

2. Donos N, Kostopoulos L, Tonetti M, Karring T. Long-term stability of autogenous bone grafts following combined application with guided bone regeneration. Clin Oral Implants Res 2005;16:133-139. doi: 10.1111/j.16000501.2004.01104.x.

3. McGinnis M, Larsen P, Miloro M, Beck FM. Comparison of resorbable and nonresorbable guided bone regeneration materials: a preliminary study. Int J Oral Maxillofac Implants 1998;13:30-35.

4. Buser D, Dula K, Belser UC, Hirt HP, Berthold H. Localized ridge augmentation using guided bone regeneration. II. surgical procedure in the mandible. Int J Periodontics Restorative Dent 1995;15:10-29.

5. Jovanovic SA, Schenk RK, Orsini M, Kenney EB. Supracrestal bone formation around dental implants: an experimental dog study. Int J Oral Maxillofac Implants 1995;10: 23-31.

6. Van Steenberghe D, Johansson C, Quirynen M, Molly L, Albrektsson T, Naert I. Bone augmentation by means of a stiff occlusive titanium barrier. Clin Oral Implants Res 2003;14: 63-71.

7. Eisig SB, Ho V, Kraut R, Lalor P. Alveolar ridge augmentation using titanium micromesh: an experimental study in dogs. J Oral Maxillofac Surg 2003;61:347-353. doi: 10.1053/joms.2003.50064.

8. Her S, Kang T, Fien MJ. Titanium mesh as an alternative to a membrane for ridge augmentation. J Oral Maxillofac Surg 2012;70:803-810. doi: 10.1016/j.joms.2011.11.017.

9. Yamada Y, Hara K, Nakamura S, Ueda M, Ito K, Nagasaka T. Minimally invasive approach with tissue engineering for severe alveolar bone atrophy case. Int J Oral Maxillofac
Surg 2013;42:260-263. doi: 10.1016/j.ijom.2012.07.003.

10. von Arx T, Hardt N, Wallkamm B. The TIME technique: a new method for localized alveolar ridge augmentation prior to placement of dental implants. Int J Oral Maxillofac Implants 1996;11:387-394.

11. Artzi Z, Dayan D, Alpern Y, Nemcovsky CE. Vertical ridge augmentation using xenogenic material supported by a configured titanium mesh: clinicohistopathologic and histochemical study. Int J Oral Maxillofac Implants 2003;18: 440-446.

12. Roccuzzo M, Ramieri G, Spada MC, Bianchi SD, Berrone $S$. Vertical alveolar ridge augmentation by means of a titanium mesh and autogenous bone grafts. Clin Oral Implants Res 2004;15:73-81.

13. Roccuzzo M, Ramieri G, Bunino M, Berrone S. Autogenous bone graft alone or associated with titanium mesh for vertical alveolar ridge augmentation: a controlled clinical trial. Clin Oral Implants Res 2007;18:286-294. doi: 10.1111/ j.1600-0501.2006.01301.x.

14. Lee KH, Kwon YH, Park JB, Herr Y. Effect of pore number of titanium mesh on bone formation in the procedure of GBR. J Korean Acad Periodontol 2004;34:411-424.

15. Hong SB, Kwon YH, Park JB, Herr Y, Chung JH. Effect of bone graft materials on bone formation in guided bone regeneration using perforated titanium membrane. J Korean Acad Periodontol 2006;36:223-237. doi: 10.5051/ jkape.2006.36.1.223.

16. Louis PJ, Gutta R, Said-Al-Naief N, Bartolucci AA. Reconstruction of the maxilla and mandible with particulate bone graft and titanium mesh for implant placement. J Oral Maxillofac Surg 2008;66:235-245. doi: 10.1016/ j.joms.2007.08.022.

17. Proussaefs P, Lozada J. Use of titanium mesh for staged localized alveolar ridge augmentation: clinical and histologic-histomorphometric evaluation. J Oral Implantol 2006;32:237-247. doi: 10.1563/1548-1336(2006) 32[237:UOTMFS]2.0.CO;2.

18. von Arx T, Wallkamm B, Hardt N. Localized ridge augmentation using a micro titanium mesh: a report on $27 \mathrm{im}-$ plants followed from 1 to 3 years after functional loading. Clin Oral Implants Res 1998;9:123-130.

19. Simion M, Baldoni M, Rossi P, Zaffe D. A comparative study of the effectiveness of e-PTFE membranes with and without early exposure during the healing period. Int J Periodontics Restorative Dent 1994;14:166-180.

20. Tal H, Kozlovsky A, Artzi Z, Nemcovsky CE, Moses O. Longterm bio-degradation of cross-linked and non-cross-linked collagen barriers in human guided bone regeneration. Clin Oral Implants Res 2008;19:295-302. doi: 10.1111/j.16000501.2007.01424.x.

21. Corinaldesi G, Pieri F, Marchetti C, Fini M, Aldini NN, Giardino R. Histologic and histomorphometric evaluation of alveolar ridge augmentation using bone grafts and tita- 
nium micromesh in humans. J Periodontol 2007;78:14771484. doi: 10.1902/jop.2007.070001.

22. Cucchi A, Vignudelli E, Napolitano A, Marchetti C, Corinaldesi G. Evaluation of complication rates and vertical bone gain after guided bone regeneration with non-resorbable membranes versus titanium meshes and resorbable membranes. a randomized clinical trial. Clin Implant Dent Relat Res 2017;19:821-832. doi: 10.1111/cid.12520. 